\title{
Exploring the contributions of two glutamate decarboxylase isozymes in Lactobacillus brevis to acid resistance and $\gamma$-aminobutyric acid production
}

Changjiang Lyu ${ }^{1,2}$, Weirui Zhao ${ }^{3}$, Chunlong Peng ${ }^{2}$, Sheng Hu ${ }^{3}$, Hui Fang ${ }^{1}$, Yujiao Hua ${ }^{1}$, Shanjing Yao ${ }^{2}$, Jun Huang ${ }^{*^{*}}$ and Lehe $\mathrm{Mei}^{2,3^{*}}$

\begin{abstract}
Background: The glutamate decarboxylase (GAD) system of Lactobacillus brevis involves two isoforms of GAD, GadA and $\mathrm{GadB}$, which catalyze the conversion of L-glutamate to $\gamma$-aminobutyric acid (GABA) in a proton-consuming reaction contributing to intracellular pH homeostasis. However, direct experimental evidence for detailed contributions of gad genes to acid tolerance and GABA production is lacking.

Results: Molecular analysis revealed that gadB is cotranscribed in tandem with upstream gadC, and that expression of gadCB is greatly upregulated in response to low ambient $\mathrm{pH}$ when cells enter the late exponential growth phase. In contrast, gadA is located away from the other gad genes, and its expression was consistently lower and not induced by mild acid treatment. Analysis of deletion mutations in the gad genes of L. brevis demonstrated a decrease in the level of GAD activity and a concomitant decrease in acid resistance in the order of wildtype $>\triangle g a d A>\triangle g a d B>\triangle g a d C>\triangle g a d A B$, indicating that the GAD activity mainly endowed by GadB rather than GadA is an indispensable step in the GadCB mediated acid resistance of this organism. Moreover, engineered strains with higher GAD activities were constructed by overexpressing key GAD system genes. With the proposed two-stage $\mathrm{pH}$ and temperature control fed-batch fermentation strategy, GABA production by the engineered strain L. brevis 9530: pNZ8148-gadBC continuously increased reaching a high level of $104.38 \pm 3.47 \mathrm{~g} / \mathrm{L}$ at $72 \mathrm{~h}$.
\end{abstract}

Conclusions: This is the first report of the detailed contribution of gad genes to acid tolerance and GABA production in L. brevis. Enhanced production of GABA by engineered L. brevis was achieved, and the resulting GABA level was one of the highest among lactic acid bacterial species grown in batch or fed-batch culture.

Keywords: Lactobacillus brevis, GAD system, GABA, Acid resistance

\footnotetext{
*Correspondence: huangjun@zust.edu.cn; meilh@zju.edu.cn

${ }^{1}$ School of Biological and Chemical Engineering, Zhejiang University

of Science and Technology, Hangzhou 310023, China

${ }^{2}$ College of Chemical and Biological Engineering, Zhejiang University,

Hangzhou 310027, China

Full list of author information is available at the end of the article
} 


\section{Background}

Lactic acid bacteria (LAB) comprise a heterogeneous group of commercially important microorganisms extensively utilized in a large variety of food fermentations including dairy, meat, fish and vegetable products [1]. The growth of LAB is characterized by the generation of acidic end products of fermentation, which accumulate in the extracellular environment, lowering the $\mathrm{pH}$ and preventing the growth of spoilage bacteria $[2,3]$. This distinctive feature is the basis of widely practiced methods of food preservation via fermentation [4]. However, acidification also has a detrimental effect on the cellular physiology of LAB, reducing the activity of acid-sensitive enzymes and damaging proteins and DNA. As the roles or functions of LAB are directly related to their acidogenicity (ability to produce acid at low $\mathrm{pH}$ ) and acidurance (capacity to function at low $\mathrm{pH}$ ) [5], it is important to understand how $\mathrm{LAB}$ sense and subsequently adapt to the acidic environment and what contributes to these adaptations.

Living cells are critically dependent on cytoplasmic $\mathrm{pH}$ homeostasis because most proteins have distinct $\mathrm{pH}$ ranges within which they can function $[6,7]$. To counteract the acidification of the extracellular environment, LAB employ a complex but efficient combination of active and passive acid resistance systems $[7,8]$. Remarkably, among various types of acid responses and tolerance mechanisms, the GAD system is regarded as one of the most potent acid mitigating pathways. In this system, intracellular protons are consumed through decarboxylation of glutamate in the cytoplasm and exchange of the reaction product GABA with extracellular glutamate, which contributes to protecting cells from the acid stress encountered during food fermentation and in the gastrointestinal tract $[9,10]$.

The existence and mode of action of the GAD system was first examined in LAB more than 65 years ago [11]. In addition to being the major acid survival pathway was confirmed in Lactococcus lactis [9] and Lactobacillus reuteri [12], the glutamate-dependent system has also been studied in LAB due to the link between glutamate decarboxylation and ATP synthesis through the generation of a proton motive force (PMF) [13]. Moreover, by combining the attributes of a GRAS status of food fermenting $L A B$ and the physiological functions of GABA in the mammalian central nervous system, such as hypotensive, hepatic encephalopathy and diabetes reduction [14-16], many researchers have focused on investigations into GABA-producing LAB from various viewpoints. Some of these perspectives include the genetic and biochemical characterization of GAD, and GABA production based on the medium composition or fermentation condition $[17,18]$.
Among a variety of reported $\mathrm{LAB}$ species, Lactobacillus brevis strains are the most frequently isolated from traditional fermented products with the highest GABA productivity $[17,19,20]$. GABA production using $L$. brevis as bacterial cell factories is therefore a focus of research [21-24]. Previous investigations have shown that in contrast to other LAB species, the L. brevis chromosome generally contains distinct genes encoding two biochemically identical isoforms of GAD: GadA and GadB [23, $25,26]$. Additionally, the gadC gene, located upstream of gadB, has been proposed to encode the antiporter implicated in GABA export $[23,26]$. Notably, although transcriptional levels in several $L$. brevis strains are typically analyzed by measurements of relevant mRNA abundance $[23,26,27]$, the physiological role and regulatory mechanism of the GAD system in this species remains largely unclear. In addition, direct experimental evidence for the detailed contribution, if any, of gad genes to the acid tolerance and GABA production of $L$. brevis is lacking.

Because understanding the role and regulation of the GAD system is a prerequisite for exploiting such characteristics of acid resistance and GABA production, it is necessary to gain a deeper insight of role of the glutamate decarboxylase-dependent system in the physiology of $L$. brevis. To address the above issues, in the present work we focused our attention on the high GABA-producing strain L. brevis CGMCC1306 [21, 28, 29], with the aim of identifying genes that may explain its ability to grow under acid conditions and its GABA production. To further enhance GABA production from $L$-monosodium glutamate (MSG), recombinant L. brevis strains overexpressing GAD system key genes were constructed based on a nisin-controlled gene expression system (NICE) [30]. Moreover, a two-stage $\mathrm{pH}$ and temperature control with substrate feeding strategy was also developed to enhance the production of GABA.

\section{Results}

\section{Gene locus of GAD system in L. brevis CGMCC1306}

The genetic determinants of the GAD system in several representative strains of LAB were characterized, as shown in Fig. 1. The gene organization present in $L$. brevis differs from the previously characterized GAD gene clusters in L. lactis [9], Lactobacillus acidophilus [31] and L. reuteri [32]. In particular, sequence analysis revealed that existence of two different GAD-encoding genes ( $\mathrm{gadA}$ and $\mathrm{gadB}$ ) in strain CGMCC1306. Indeed, this is a common characteristic shared by L. brevis strains (Fig. 2), except for L. brevis NCL912, with only one cloned gene encoding GAD [27]. The $\operatorname{gadB}$ is linked to the glutamate/GABA antiporter gene $(\operatorname{gadC})$, and gadA is located separately from the other gad genes. In E. coli [33], Shigella flexneri [34] and Brucella microti 


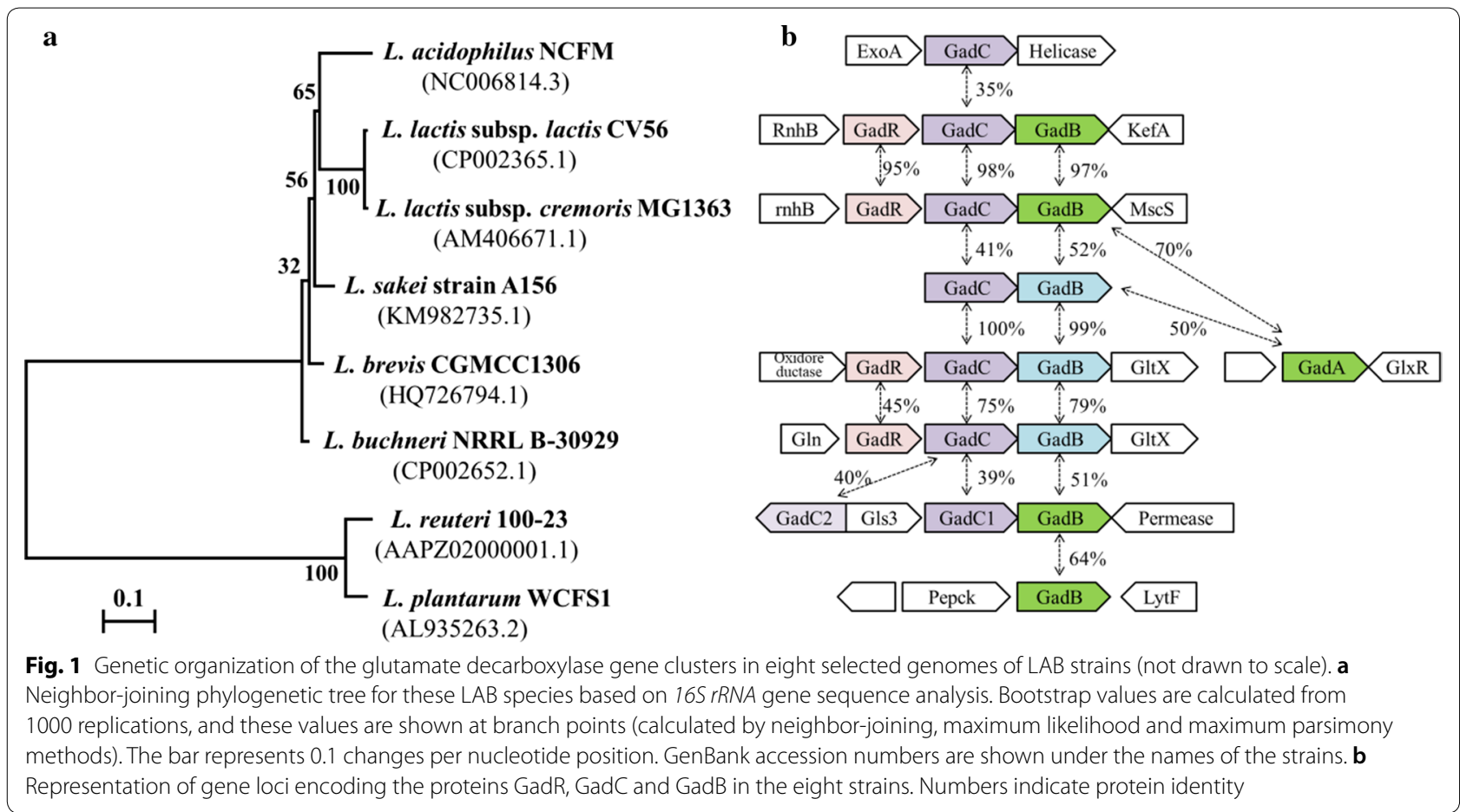

[35], gadC genes are preceded by $\operatorname{gadB}$, whereas the gene order in L. brevis is $\operatorname{gadC}$ followed by $\operatorname{gadB}$. The $\operatorname{gadC}$ gene is preceded by an 8-bp inverted repeat (IR; $\left.\Delta \mathrm{G}\left[25^{\circ} \mathrm{C}\right]=-9.5 \mathrm{kcal} / \mathrm{mol}\right)$ and a possible ribosomebinding site (Additional file 1). In addition, no putative promoter or terminator signals were identified in the 52-bp intergenic region between $\operatorname{gad} C$ and $\operatorname{gadB}$, which suggests that they may form an operon, i.e., gadCB.

An additional gene, $\operatorname{gadR}$, located upstream of $\operatorname{gadC}$ codes for a putative transcriptional regulator of $\operatorname{gad} C B$. The deduced amino acid sequence is homologous (66\% identify) to GadR, a possible positive regulator involved in expression of gadCB in L. brevis NCL912 [27]. Similarly, gadR is preceded by an 18 -bp inverted repeat (IR; $\Delta \mathrm{G}\left[25^{\circ} \mathrm{C}\right]=-18.2 \mathrm{kcal} / \mathrm{mol}$ ) and a possible ribosome-binding site (Additional file 1), which suggests that transcription of $\operatorname{gadR}$ might be independent of the $\operatorname{gadCB}$ operon. In particular, the $\operatorname{gadRCB}$ gene cluster in L. brevis CGMCC1306 shows the same gene order and organization as in L. lactis subsp. lactis CV56, L. lactis subsp. cremoris MG1363 and L. buchneri NRRL B-30929. However, there is no evidence that the $\operatorname{gadR}$ gene exists in other LAB species, except for strain L. sakei A156, the genome sequence of which has not yet been published [36]. In line with these differences, gadC and gadB of L. brevis and those genes of $L$. sakei share high sequence identity but are more distantly related to these genes in L. lactis, L. reuteri and L. plantarum.

\section{Expression of the gadCB operon is $\mathrm{pH}$-dependent}

To determine whether gad system genes in L. brevis CGMCC1306 are subject to acid-induced transcriptional regulation, a reverse-transcription quantitative PCR assay was performed in which the expression levels of all four gad genes were determined. When cells were grown in yeast extract peptone (GYP) medium under acidic conditions ( $\mathrm{pH}$ 5.2), the relative expression levels of $\operatorname{gadR}, \operatorname{gadC}$ and $\operatorname{gadB}$ differed by 0.2 - to 17.4-fold from the control group (cells cultured in GYP medium for $6 \mathrm{~h}$ ). The highest expression levels were found in the case of the last two genes of the gad cluster, $\operatorname{gadC}$ and $\operatorname{gadB}$. Moreover, transcription of $\mathrm{gadC}$ and $\mathrm{gadB}$ was synchronous (Fig. 3b). The expression level was highest at the late exponential phase of growth. Upon further fermentation, a sharp decline in overall relative expression levels of the gad genes was observed from the start of the stationary growth phase. At $\mathrm{pH} 6.8$, a less pronounced decrease in the relative expression levels of gad cluster genes was found compared to those at pH 5.2. As shown in Fig. 3d, the increased expression of $\operatorname{gadRCB}$ genes was nearly undetectable. Notably, overall expression of $\operatorname{gadA}$ gene was consistently low and did not change in response to acid ( $\mathrm{pH}$ 5.2) or neutral ( $\mathrm{pH}$ 6.8) conditions. These results clearly demonstrate that expression of the $\operatorname{gadCB}$ operon is $\mathrm{pH}$ dependent, while expression of the gadA gene is constitutive. In addition, the transcriptional level of $\operatorname{gad} C$ was identical to that of $\operatorname{gadB}$, further suggesting the existence of a $\operatorname{gad} C B$ operon in this strain. Indeed, this 


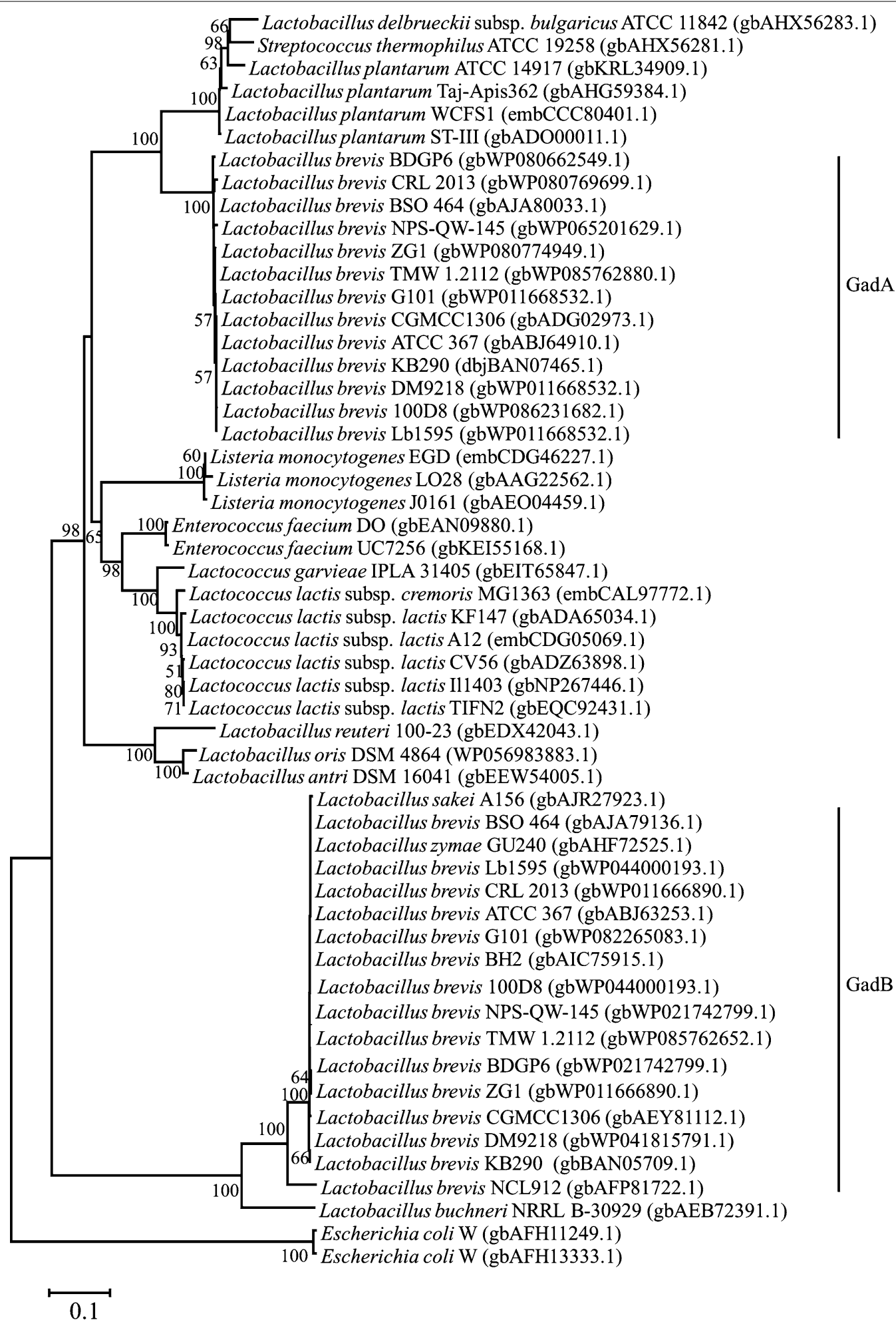

Fig. 2 Phylogenetic tree based on deduced amino acid sequences of glutamic acid decarboxylases. Glutamate decarboxylase homologs from various representative organisms were aligned using ClustalX, and the phylogenetic tree was constructed with the neighbor-joining (NJ) method using MEGA 4.0. GenBank accession numbers are shown for all proteins. The numbers at the branches indicate supporting bootstrap values (1000 replications) for the NJ analyses. Bootstrap values above $50 \%$ are shown 

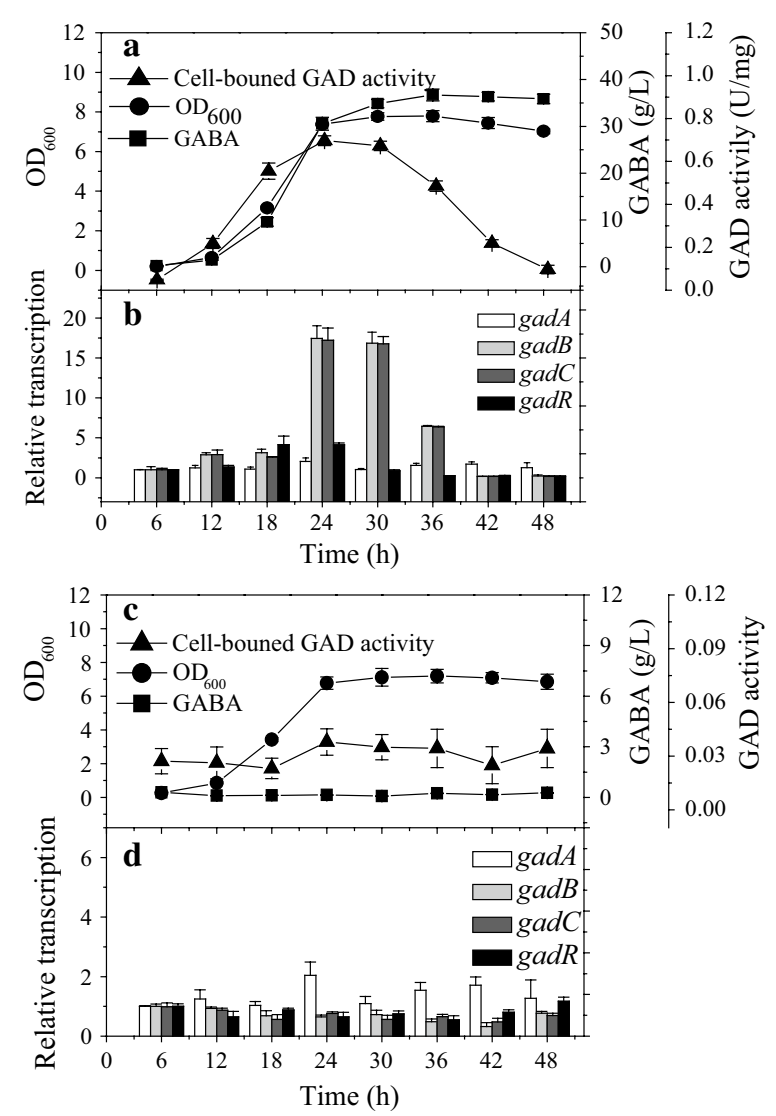

Fig. 3 Growth and GABA production of L. brevis CGMCC1306 during fermentation at different constant pH values: $\mathrm{pH} 5.2$ (a) or pH 6.8 (c). The relative transcription level of gad genes during fermentation with the $\mathrm{pH}$ maintained at different constant pH values: 5.2 (b) or 6.8 (d). The values presented are the means of three replicate cultures; error bars representing standard deviations may be obscured by symbols

is consistent with PCR analysis verification (Additional file 2).

To explore the relationship between gad gene expression and GABA levels, GABA concentrations were determined under different fermentation conditions. The results showed that $\mathrm{pH}$ had a significant effect on the kinetics of MSG conversion and cell-bound GAD activity. As shown in Fig. 3a, when 75 g/L of MSG was used as the substrate, $34.9 \mathrm{~g} / \mathrm{L}$ of GABA was produced after $30 \mathrm{~h}$ of batch reaction under acidic conditions ( $\mathrm{pH}$ 5.2).
Conversely, no obvious conversion of MSG to GABA occurred in $\mathrm{pH}$-controlled fermenters at a $\mathrm{pH}$ value of 6.8 (Fig. 3c). Overall, there was a good correlation between expression of gadRCB and GABA production in L. brevis CGMCC1306.

\section{GAD activity assays using deletion mutants}

A positive correlation between cells possessing GAD activity and the gene expression levels of the $\operatorname{gadCB}$ operon was observed, suggesting that $L$. brevis CGMCC1306 may employ gadCB gene products rather than GadA for its main GAD activity. To investigate this possibility, deletions in $\operatorname{gadC}$, $\operatorname{gadA}$ and/or $\operatorname{gadB}$ were generated using the double crossover homologous recombination method, as described previously [37]. Because different GAD activities were observed during the various growth phases (Fig. 3a), the GAD activity assay was conducted on parent and mutant strains under two conditions: cells in exponential (EXP.; $12 \mathrm{~h}$ ) and early stationary (EARLY-STAT.; $30 \mathrm{~h}$ ) phases (Table 1). For exponential phase cells, deletion of gadA resulted in a small reduction in cell-bound GAD activity; however, deletion of $\operatorname{gadB}$ in $L$. brevis led to a more significant decrease, reducing activity by approximately 16.2-fold. As expected, GAD activity was essentially eliminated in the $\triangle \operatorname{gad} A \operatorname{gadB}$ double mutant. It is noteworthy that very low levels of activity remained in the $\Delta \operatorname{gadC}$ mutant, and this unexpected result might have been caused by some degree of cell lysis resulting in extracellular GadB and GadA activity. In further experiments, a roughly similar trend was observed in early stationary-phase cells (Table 1). No activity was observed for the $\Delta \operatorname{gad} A \Delta \operatorname{gadB}$ double mutant, and only slight activity was found for the $\triangle$ gadC mutant.

Analysis of a set of four gad deletion mutants demonstrated a dramatic decrease in the level of cell-bound GAD activity in the order of wildtype $>\Delta \operatorname{gad} A>\Delta \operatorname{gad} B>\Delta \operatorname{gad} C>\Delta \operatorname{gad} A \Delta \operatorname{gadB}$ (Table 1), indicating that GadB rather than GadA was the main contributor to the overall GAD activity under this condition. Moreover, these data indicate that this strain has no third GAD that is sufficiently active under the tested conditions to substitute for GadB. These combined results strongly suggest that $\mathrm{pH}$-dependent $\mathrm{GadC}$ and GadB play a more important role in overall

Table 1 Cell-bound GAD activity

\begin{tabular}{|c|c|c|c|c|c|}
\hline & WT (U/g DCW) & $\triangle \operatorname{gadA}(\mathrm{U} / \mathrm{g} D C W)$ & $\Delta \operatorname{gadB}(\mathrm{U} / \mathrm{g} \mathrm{DCW})$ & $\triangle \operatorname{gad} A B(\mathrm{U} / \mathrm{g} \mathrm{DCW})$ & $\Delta \operatorname{gadC}(\mathrm{U} / \mathrm{g}$ DCW) \\
\hline EXP. & $218.13 \pm 23.18$ & $173.56 \pm 8.75$ & $13.44 \pm 2.67$ & $0.05 \pm 0.02$ & $0.75 \pm 0.09$ \\
\hline EARLY-STAT. & $672.72 \pm 22.04$ & $605.47 \pm 30.12$ & $22.49 \pm 7.43$ & $0.08 \pm 0.07$ & $1.96 \pm 0.14$ \\
\hline
\end{tabular}

Cells were collected at the exponential phase (EXP; $12 \mathrm{~h}$ ) and early stationary phase (EARLY-STAT.; $30 \mathrm{~h}$ ). One unit (U) of GAD activity was defined as the mass of cells that produced $1 \mu \mathrm{mol}$ of GABA in $1 \mathrm{~min}$. Specific activity was defined as $\mathrm{U} / \mathrm{g}$ dry cell weight (DCW) of cells 
Table 2 Cytoplasmic GAD activities of $L$. brevis strains

\begin{tabular}{|c|c|c|c|c|c|c|}
\hline & $\begin{array}{l}\mathrm{WT}(\mathrm{U} / \mathrm{mg} \\
\text { of protein) }\end{array}$ & $\begin{array}{l}\Delta \text { gadA }(\mathrm{U} / \mathrm{mg} \\
\text { of protein) }\end{array}$ & $\begin{array}{l}\Delta g a d B(U / m g \\
\text { of protein) }\end{array}$ & $\begin{array}{l}\Delta g a d A \Delta g a d B(\mathrm{U} / \mathrm{mg} \\
\text { of protein) }\end{array}$ & $\begin{array}{l}\Delta \text { gadC }(\mathrm{U} / \mathrm{mg} \\
\text { of protein) }\end{array}$ & $\begin{array}{l}\Delta g a d B: p M G 36 e-g a d B \\
\text { (U/mg of protein) }\end{array}$ \\
\hline EXP. & $1.31 \pm 0.09$ & $1.24 \pm 0.16$ & $0.19 \pm 0.08$ & $0.04 \pm 0.02$ & $1.35 \pm 0.17$ & $3.82 \pm 0.27$ \\
\hline
\end{tabular}

Cells were collected at exponential phase (EXP.; $24 \mathrm{~h}$ ) and then lysed by passing them three times through a French pressure cell press at 20,000 p.s.i., and GAD activity in the supernatant fraction was determined. One unit (U) of GAD activity was defined as the amount of enzyme that produced $1 \mu \mathrm{mol}$ of GABA in 1 min. Specific activity is expressed as $\mathrm{U} / \mathrm{mg}$ of protein

GAD activity relative to GadA, at least under the conditions tested in this study. Remarkably, in contrast with the cell-bound GAD activities measured in these mutants, the cytoplasmic GAD activity of $L$. brevis $\triangle \operatorname{gadC}$ was similar to that of the wild-type strain (Table 2). This result demonstrates that GAD functions in strict association with a cognate GadC, which is localized to the cell membrane and provides a selective gate for the entry of glutamate and exit of the decarboxylation product GABA [38].

\section{The gadCB operon contributes to survival under acidic conditions}

To confirm that gadCB of L. brevis CGMCC1306 encodes proteins contributing to acid resistance, the survival of the mutants at $\mathrm{pH} 2.5$ was compared with that of the wild-type strain. As shown in Fig. 4, all mutants were more sensitive to the acid challenge in the presence of MSG than the parent strain, and this distinction became more apparent over time. Similar to cell-bound GAD activity, the cell survival rate of the L. brevis $\triangle$ gadA mutant was only minimally lower after acid challenge for $5 \mathrm{~h}$. However, mutant strains involving either $\operatorname{gadC}$ or $\operatorname{gadB}$ were dramatically more sensitive to acid. Additionally, this transition in the gadC mutant tended to be more obvious as the duration of exposure to low $\mathrm{pH}$ increased. Notably, the most dramatic decreases were observed with the exquisitely sensitive $\Delta \operatorname{gad} A \Delta \operatorname{gadB}$ mutant, which showed an approximately $1.7-\log$ reduction in survival relative to the wild-type strain after exposure to acid for $5 \mathrm{~h}$. Moreover, it was also noted that the sensitivity of the $\triangle \operatorname{gadB}$ complementation strain L. brevis $\triangle \operatorname{gadB}$ : pMG36e-gadB was less than that of the $\triangle \operatorname{gadB}$ mutant and wild-type in this phase of growth (Fig. 4), which corresponds well with the GAD activity data reported above (Table 2). In conclusion, $L$. brevis mutants deleted for $\operatorname{gadC}$ or $\operatorname{gadB}$ were sensitive to acid, which indicates that both glutamate decarboxylase and the antiporter are essential for acid resistance. Furthermore, GadB, together with GadC, confer glutamatedependent acid resistance to this LAB, with GadA playing a minor role.

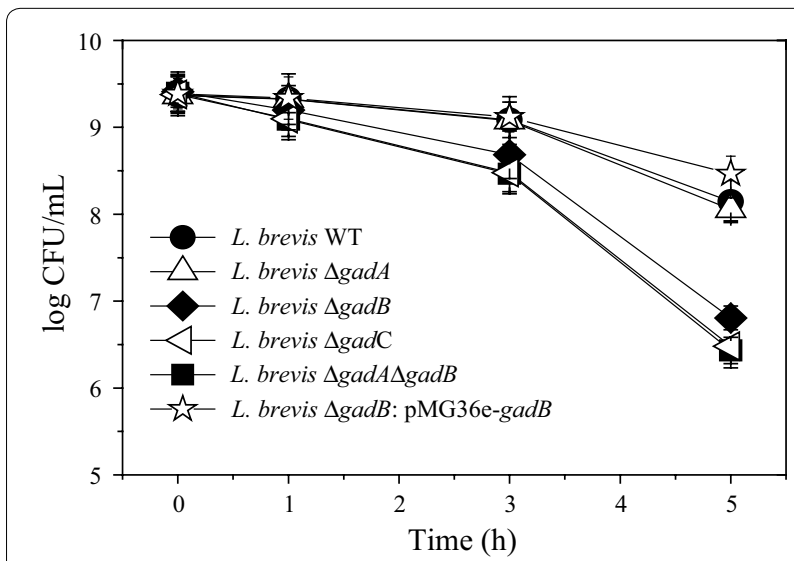

Fig. 4 Acid resistance of L. brevis strains in phosphate buffer $(\mathrm{pH} 2.5)$ with $10 \mathrm{mmol} / \mathrm{L}$ MSG. Stationary-phase cells of L. brevis CGMCC1306 (WT), L. brevis $\triangle$ gadA, L. brevis $\triangle g a d B$, L. brevis $\triangle$ gadC, L. brevis $\triangle$ gadA $\triangle$ gadB and L. brevis $\triangle$ gadB: pMG36e-gadB were exposed to a pH of 2.5, and the numbers of viable cells were estimated over time. Standard deviations were calculated from the results of three independent experiments

\section{Enhancement of $L$. brevis GAD activity by increasing expression of key GAD system genes}

Upon observing that the pH-dependent GadC and GadB proteins were the greatest contributors to GABA production during the fermentation process, we hypothesized that increasing the expression of key GAD system genes may improve the overall GAD activity of $L$. brevis. Therefore, the $\operatorname{gad} B$ and $\operatorname{gadCB}$ segments were cloned into the nisin-inducible expression vector pNZ8148 [39] and subsequently transformed into L. brevis 9530 [28] to form L. brevis 9530: pNZ8148-gadB and L. brevis 9530: pNZ8148-gadCB, respectively. Considering the gene order of $\operatorname{gadB}$ and $\operatorname{gadC}$ in the genomes of E. coli [33], $S$. flexneri [34] and B. microti [35], another recombinant plasmid, pNZ8148-gadBC was also obtained and transformed into strain L. brevis 9530. In cells, gadB and gadC expression was under the control of the nisin-inducible nisA promoter (Additional file 3). After induction with $10 \mathrm{ng} / \mathrm{mL}$ nisin, samples of recombinant L. brevis strains grown in GYP fermentation medium under acidic conditions ( $\mathrm{pH}$ 5.2) were collected at intervals during cultivation for extraction or determination of cell-bound GAD 
activity. According to SDS-PAGE analysis of whole-cell proteins, the bands observed were consistent with the predicted molecular mass of GadB $(53.5 \mathrm{kDa})$ and GadC (55.2 kDa; Additional file 3), indicating that the two enzymes were well expressed under the nis $A$ promoter in L. brevis.

To evaluate whether overexpression of $\mathrm{GadB}$ and GadC effectively enhanced GABA productivity, the GAD activities of these engineered $L$. brevis strains were measured. As shown in Fig. 5, after $24 \mathrm{~h}$ of incubation, the cell-bound GAD activities of $L$. brevis 9530: pNZ8148$\operatorname{gadB}$, L. brevis 9530: pNZ8148-gadCB and L. brevis 9530: pNZ8148-gadBC were $0.83 \pm 0.06,0.95 \pm 0.04$ and $1.07 \pm 0.08 \mathrm{U} / \mathrm{mg} \mathrm{DCW}$, respectively. As expected, all three recombinant strains exhibited higher activities than did the wild-type strain $(0.69 \pm 0.02 \mathrm{U} / \mathrm{mg} D C W)$. In addition, the increased GAD activity in the recombinant L. brevis strain harboring pNZ9530/pNZ8148-gadBC system was the best compared to that of the other strains. Therefore, this strain was selected for a thorough characterization of GABA production.

\section{Enhanced production of GABA using a two-stage $\mathrm{pH}$ and temperature control with substrate feeding strategy} Temperature and $\mathrm{pH}$ are two of the well-documented factors influencing cell growth and activity during fermentation $[17,29]$. To achieve optimal conditions for maximum yield of GABA, the effects of $\mathrm{pH}$ and temperature on the growth and GAD activity of $L$. brevis cells were determined. At low temperatures, the specific growth rate of $L$. brevis 9530: pNZ8148-gadBC and L. brevis CK increased as temperature increased, with the maximum value observed at $35^{\circ} \mathrm{C}$, above which the specific growth

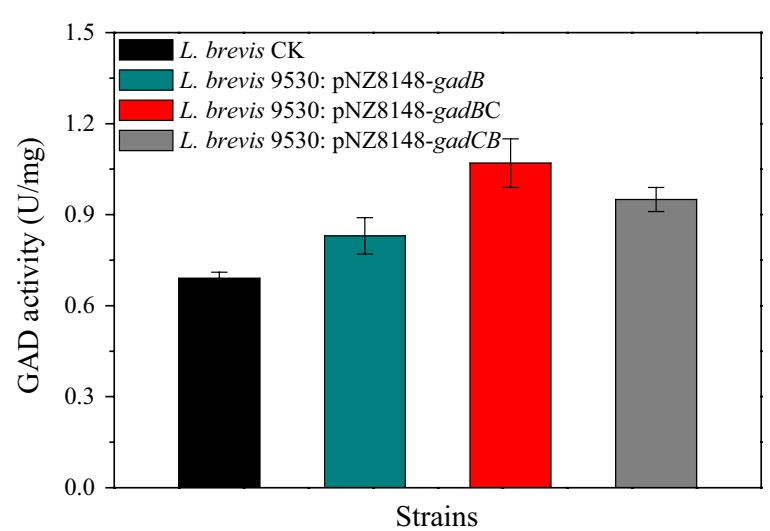

Fig. 5 Cell-bound GAD activities of recombinant L. brevis strains. Cells were collected at exponential-phase (24 h). One unit (U) of GAD activity was defined as the amount of cells that produced $1 \mu \mathrm{mol} / \mathrm{L}$ of GABA in 1 min at $\mathrm{pH}$ 4.8. The specific activity of GAD was defined as $\mathrm{U} / \mathrm{mg} \mathrm{DCW}$ rate tended to decrease (Fig. 6a). Similarly, the effect of $\mathrm{pH}$ on the specific growth rate is shown in Fig. 6b. The optimum $\mathrm{pH}$ for growth of engineered strain was $\mathrm{pH}$ 5.2, which was also consistent with that of $L$. brevis CK. Furthermore, the effect of temperature on cell-bound GAD activity was examined at temperatures ranging from 20 to $50{ }^{\circ} \mathrm{C}$ (Fig. $6 \mathrm{c}$ ). At $20{ }^{\circ} \mathrm{C}$, the GAD activity of the engineered strain $(0.20 \pm 0.03 \mathrm{U} / \mathrm{mg} \mathrm{DCW})$ was similar to that of the control strain $(0.16 \pm 0.02 \mathrm{U} / \mathrm{mg} \mathrm{DCW})$. As expected, GAD activity increased with temperature increase for both strains, but the increase was larger for L. brevis 9530: pNZ8148-gadBC, approximately $39.2 \%$ higher at the optimum temperature $\left(40{ }^{\circ} \mathrm{C}\right)$ than $L$. brevis $\mathrm{CK}$. Moreover, it is worth noting that the highest GAD activity of L. brevis 9530: pNZ8148-gadBC was obtained at $\mathrm{pH} 4.4$, followed by $\mathrm{pH} 4.8, \mathrm{pH} 5.2$ and $\mathrm{pH}$ 4.0 (Fig. 6d). Obviously, the optimum pH for cell growth and GAD activity is not fully coupled, as was the case for temperature.

To address the coupling of cell growth with GAD activity described above, a fed-batch fermentation with two-stage $\mathrm{pH}$ and temperature control strategy was proposed for improving GABA production. In the first stage $(0-24 \mathrm{~h}), \mathrm{pH}$ and temperature were set at $\mathrm{pH} 5.2$ and $35{ }^{\circ} \mathrm{C}$, respectively, to promote cell growth; in the second stage (24-102 h), the $\mathrm{pH}$ and temperature were changed to 4.4 and $40{ }^{\circ} \mathrm{C}$, respectively, to favor GABA production. The fermentation dynamics of $L$. brevis 9530: pNZ8148-gadBC are shown in Fig. 7. The GABA content increased rapidly with fermentation time from 12 to $48 \mathrm{~h}$ after inoculation, increased slowly from 48 to $72 \mathrm{~h}$, and then hardly increased as time progressed. After $102 \mathrm{~h}$ of fermentation, the volume of culture broth had increased to approximately $3.7 \mathrm{~L}$ due to the inoculation, substrate feeding and addition of neutralizer. Additionally, GABA concentrations were $89.45 \pm 3.24 \mathrm{~g} / \mathrm{L}, 104.38 \pm 3.47 \mathrm{~g} / \mathrm{L}$ and $105.32 \pm 2.53 \mathrm{~g} / \mathrm{L}$ at $48 \mathrm{~h}, 72 \mathrm{~h}$ and $102 \mathrm{~h}$, respectively. GABA production by strain $L$. brevis CK with the proposed two-stage fed-batch strategy was also assessed (Additional file 4). However, the GABA concentrations were found to be $72.91 \pm 2.46 \mathrm{~g} / \mathrm{L}, 82.47 \pm 2.49 \mathrm{~g} / \mathrm{L}$ and $86.35 \pm 3.71 \mathrm{~g} / \mathrm{L}$ at $48 \mathrm{~h}, 72 \mathrm{~h}$ and $102 \mathrm{~h}$, respectively, notably lower than those of the engineered strain. Based on a comprehensive consideration of GABA productivity and economic analysis, $72 \mathrm{~h}$ is recommended as the optimal fermentation time in future practical production.

\section{Discussion}

Diverse mechanisms for $\mathrm{pH}$ sensing and cytoplasmic $\mathrm{pH}$ homeostasis enable most LAB to tolerate or grow at external $\mathrm{pH}$ values that are outside the cytoplasmic $\mathrm{pH}$ range that they must maintain for growth [6, 7]. Among the most preferred mechanisms are the pumping out of 

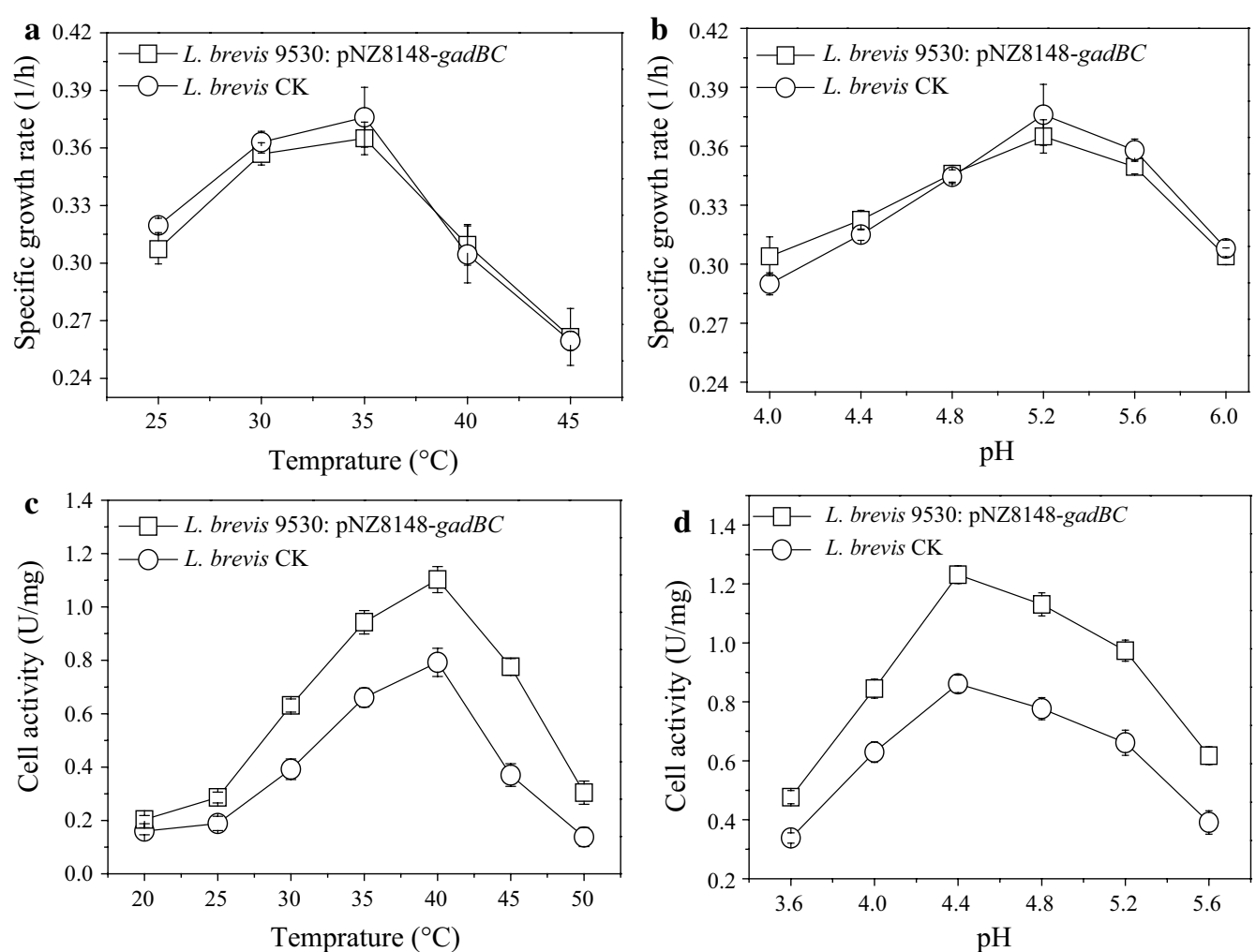

Fig. 6 Effects of temperature (a) and $\mathrm{pH}(\mathbf{b})$ on the effective maximum specific growth rate of Lb. brevis. L. brevis CK and L. brevis 9530 : pNZ8148-gadBC cells were cultured in GYP medium at different temperatures and pH values. Influence of temperature (c) and pH (d) on the cell-bound GAD activity of L. brevis. L. brevis CK and L. brevis 9530: pNZ8148-gadBC cells were grown to the late exponential growth phase (24 h) under acidic conditions ( $\mathrm{pH}$ 5.2). GAD activities were measured in $0.2 \mathrm{~mol} / \mathrm{L}$ sodium acetate buffer containing $60 \mathrm{mmol} / \mathrm{L}$ of MSG

protons, production of alkaline compounds and protonconsuming decarboxylation reactions [7]. Nonetheless, research increasingly suggests that the acid resistance of $\mathrm{LAB}$ might be strain specific and stress specific because of the genetic diversity of these acid alleviating systems among different strains [12, 23]. Furthermore, each of the various components of these pathways can be adapted in several different ways to promote survival in acidic environments [7, 32]. Therefore, the challenge becomes understanding how acid stress response systems have adapted in an individual LAB species. As mentioned above, several systems have been employed to withstand low-pH stress, but the GAD system is regarded as one of the most important pathways in some LAB strains [9, 10]. Glutamate decarboxylation to GABA contributes to the acid resistance of $E$. coli [33], Listeria monocytogenes [40], S. flexneri [34], L. lactis [9] and B. microti [35] have been characterized. However, research on the physiological function and regulatory mechanism of the GAD system in Lactobacillus species is scarce. Given the link between acid resistance phenotypes and the organization of GAD system genes, the present study was initiated to investigate the contribution of gad genes to the acid tolerance of the high GABA-producing strain L. brevis.

Lactobacillus brevis CGMCC1306 contains genes encoding two GADs (GadA and GadB) and a glutamateGABA antiporter (GadC). In E. coli, S. flexneri and B. microti, gadC genes are preceded by $\operatorname{gadB}$ [33-35], whereas $\operatorname{gadC}$ in $L$. brevis is located adjacent to but upstream of $\mathrm{gadB}$ [23]. Indeed, the arrangement of $\mathrm{gad}$ genes is a common characteristic shared by most GABAproducing LAB strains (Fig. 1b). To our knowledge, after $E$. coli and $L$. monocytogenes, $L$. brevis is only the third species in which two glutamate decarboxylase genes have been identified. Based on an analysis of the genetic organization of the GAD system, the physiological adaptation of this strain to different culture conditions was further evaluated using quantitative reverse transcription PCR. The results demonstrated that $\operatorname{gad} C B$ forms an operon in strain L. brevis CGMCC1306. Moreover, expression of the $\operatorname{gad} C B$ operon was greatly upregulated in response to low ambient $\mathrm{pH}$ when cells enter the late exponential growth phase, whereas expression of the gadA gene was consistently lower and did not change 


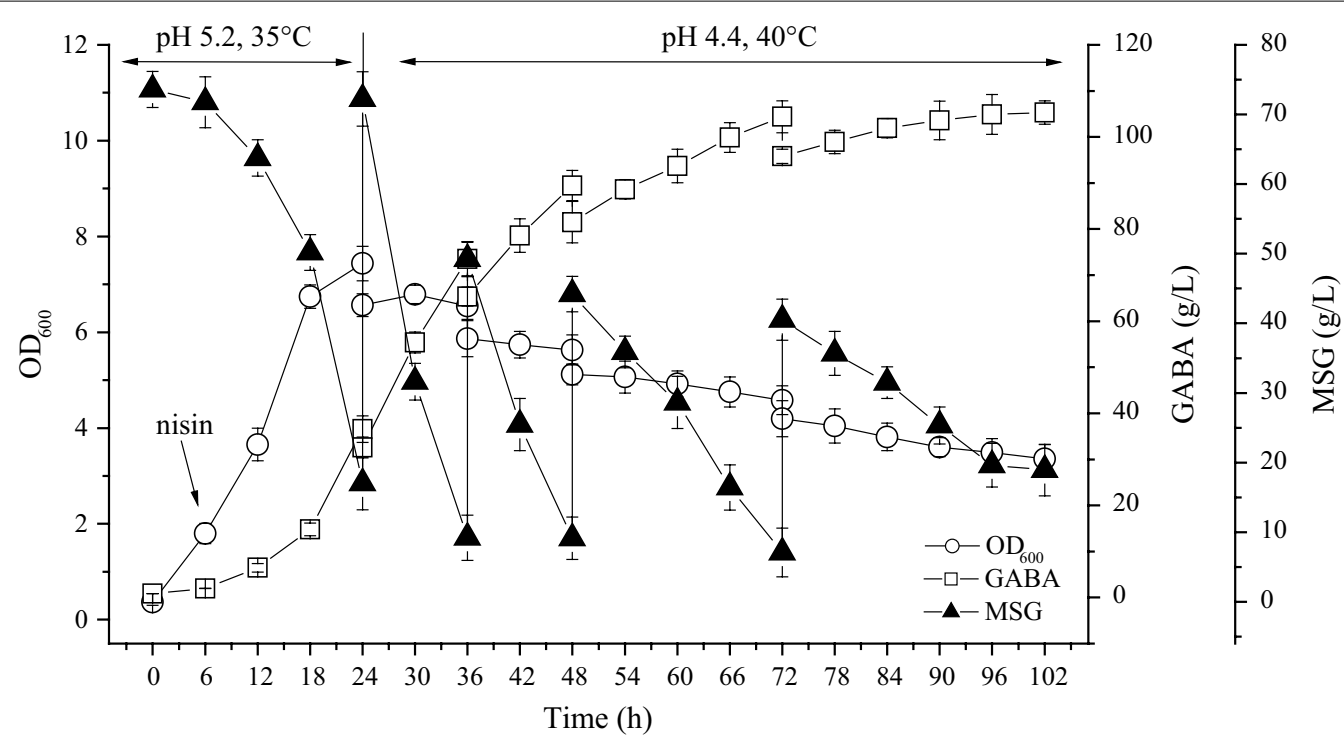

Fig. 7 Time course of cell growth, GABA production and residual MSG during the two-stage fed-batch fermentation. L. brevis 9530: pNZ8148-gadBC was cultured in a 5 - $\mathrm{L}$ fermentor under the following conditions: medium volume $2 \mathrm{~L}$, inoculum size $10 \%(\mathrm{v} / \mathrm{v})$, agitation speed $100 \mathrm{rpm}$, and fermentation time $102 \mathrm{~h}$. After cultivation at $\mathrm{pH} 5.2$ and $35^{\circ} \mathrm{C}$ for $24 \mathrm{~h}$, the culture temperature and $\mathrm{pH}$ were changed and maintained at $40^{\circ} \mathrm{C}$ and 4.4, respectively, during the second phase (24-102 h). At $24 \mathrm{~h}, 36 \mathrm{~h}, 48 \mathrm{~h}$ and $72 \mathrm{~h}, 200-\mathrm{mL}$ aliquots of MSG (140 g per aliquot) were supplemented into the bioreactor. The $\mathrm{pH}$ was maintained at the set value with the addition of $3 \mathrm{~mol} / \mathrm{L} \mathrm{H}_{2} \mathrm{SO}_{4}$ and $3 \mathrm{~mol} / \mathrm{L} \mathrm{NaOH}$

in response to acid or neutral conditions. There are also obvious differences in gadR expression levels among LAB strains. In L. brevis NCL912 [27], the expression levels of $\operatorname{gadR}$ were 13- to 155 -fold higher than those of $\operatorname{gadCB}$ throughout the culture period, though far lower expression levels were observed for $\operatorname{gadR}$ than for $\operatorname{gadCB}$ in $L$. brevis CGMCC1306. In addition, gadR in L. lactis is constitutively expressed [9].

Although transcriptional levels are typically analyzed by measurement of relevant mRNA abundance in L. brevis NCL912 [27], L. brevis TMW 1.6 [26], L. brevis TMW 1.465 [26] and L. brevis NPS-QW-145 [23], direct experimental evidence for the detailed contribution of gad genes to acid tolerance and GABA production is lacking. Therefore, a number of acid-sensitive mutants were constructed to examine the regulatory mechanisms involved in acid resistance. Similar to $L$. lactis [9], L. monocytogenes [40] and B. microti [35], L. brevis mutants deleted for $\operatorname{gadC}$ or $\operatorname{gadB}$ were acid sensitive, indicating that both glutamate decarboxylase and the antiporter are essential for the observed acid resistance of this organism. This is also in agreement with the acid sensitivity of $E$. coli and S. flexneri gadC mutants $[34,41]$ and the $L$. reuteri gadB mutant [12] identified in previous mutagenesis studies. However, a deletion in gadA resulted in only a slight loss of acid resistance. Moreover, the most acid-sensitive mutant was $L$. brevis $\triangle \operatorname{gad} A \Delta \operatorname{gadB}$, which demonstrated an approximately 1.7-log reduction in survival relative to the wild-type

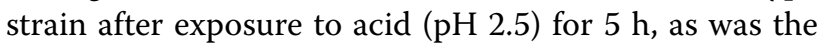
case for L. monocytogenes $\triangle \operatorname{gadA} \Delta \operatorname{gadB}[40]$. The above data can be summarized as follows in terms of acid resistance: wild-type $>\Delta \operatorname{gad} A>\Delta \operatorname{gad} B>\Delta \operatorname{gad} C>\Delta \operatorname{gad} A \Delta \operatorname{gad} B$. This trend is true for cell-associated GAD activities, as verified in L. monocytogenes [40], indicating that the ability of mutants deleted for gad genes to survive acid stress is proportional to their ability to utilize glutamate decarboxylation to consume intracellular protons. Thus, by sensing and consuming protons, glutamate decarboxylase-mediated proton consumption and the glutamate/ GABA antiporter constitute a simple molecular system that functions efficiently to protect $L$. brevis from the acid stress encountered during fermentation. Moreover, the glutamate decarboxylation activity endowed by $\mathrm{GadB}$, as opposed to that of $\mathrm{GadA}$, is an indispensable step in GadCB-mediated acid resistance and cell-bound GAD activity in L. brevis CGMCC1306.

Due to the health benefits to humans, food-fermenting $\mathrm{LAB}$ are regarded as the most suitable candidates for GABA production [17], and a wide range of LAB exhibit GAD activities [18]. Owing to the great potential in large-scale fermentation for the production of foodgrade GABA, the biotransformation of glutamate to GABA by L. brevis has been extensively investigated during the last decade $[17,23]$. Regardless, nearly all of the existing studies have focused on the optimal culture and 
transformation conditions. In this work, improving the GAD activity of $L$. brevis was achieved by increasing the expression levels of key GAD system genes. Moreover, using the proposed two-stage $\mathrm{pH}$ and temperature control fed-batch fermentation strategy, the GABA production by the genetically engineered strain $L$. brevis 9530 : pNZ8148-gadBC increased continuously, reaching a high level of $104.38 \pm 3.47 \mathrm{~g} / \mathrm{L}$ at $72 \mathrm{~h}$. Additionally, to our knowledge, the obtained GABA level is one of the highest among LAB species grown in batch or fed-batch culture.

\section{Conclusions}

In this study, the detailed contribution of gad genes to acid tolerance and GABA production in L. brevis was determined. Experimental results show that GAD activity endowed by GadB rather than that due to GadA is an indispensable step in GadCB-mediated acid resistance and cell-bound GAD activity in L. brevis CGMCC1306. Moreover, enhanced production of GABA by an engineered $L$. brevis strain was achieved using a two-stage $\mathrm{pH}$ and temperature control fed-batch fermentation strategy.
The obtained level of GABA is one of the highest among $\mathrm{LAB}$ species grown in batch or fed-batch culture.

\section{Methods \\ Bacterial strains, plasmids, and growth conditions}

The bacterial strains and plasmids used in this work are listed in Table 3. E. coli was grown aerobically with shaking at $250 \mathrm{rpm}$ in Luria-Bertani (LB) broth at 28 or $37^{\circ} \mathrm{C}$. L. lactis MG1363 was grown at $28{ }^{\circ} \mathrm{C}$ in M17 medium supplemented with $0.5 \%$ glucose (GM17). L. brevis CGMCC1306 was generally cultured in MRS medium at 28 or $37^{\circ} \mathrm{C}$ without agitation. Solid media for plating were prepared by adding $1.5 \%$ agar to the appropriate liquid media. Selective medium contained 5,7 or $200 \mu \mathrm{g} /$ $\mathrm{mL}$ erythromycin for selection of L. lactis, L. brevis or E. coli, respectively. Similarly, medium containing 10 or $20 \mu \mathrm{g} / \mathrm{mL}$ chloramphenicol was used for the selection of L. brevis or E. coli, respectively.

\section{Fermentation experiments}

During batch and fed-batch fermentations, L. brevis cells were grown in glucose yeast extract peptone

Table 3 Bacterial strains and plasmids

\begin{tabular}{|c|c|c|}
\hline Strain/plasmid & Characteristics & Source/references \\
\hline \multicolumn{3}{|l|}{ Strains } \\
\hline E. coli DH5a & $\begin{array}{l}\text { Transformation host; F- } \varphi 80 \text { lacZ } \triangle \mathrm{M} 15 \Delta(\text { lacZYA-argF) U169 recA1 endA1 hsdR17 (rk-, mk+) } \\
\text { phoA supE44 } \lambda \text { - thi-1 gyrA96 relA1 }\end{array}$ & Invitrogen \\
\hline E. coli MC1061 & $\begin{array}{l}\text { Transformation host; } \lambda \text { F } \Delta \text { (araA-leu) } 7697 \text { araD139 } \Delta \text { (codB-lac)3= }=\text { lac74 ga/K16 galE15 mcrA0 } \\
\text { relA1 rpsL150 spoT1 mcrB9999 hsdR2 (Str') }\end{array}$ & Mobitec \\
\hline E. coli XL1-Blue & $\begin{array}{l}\text { Transformation host; recA1 endA1 gyrA96 thi-1 hsdR17 supE44 relA1 lac[F' proAB laclqZ } \Delta \mathrm{M} 15 \\
\text { Tn10 Tet'] }\end{array}$ & Stratagene \\
\hline L. lactis MG1363: pGhost4 & L. lactis MG1363 harboring a temperature sensitive plasmid-pGhost4 & {$[42]$} \\
\hline L. brevis CGMCC 1306 & Wild-type strain, originally isolated from raw milk & \\
\hline L. brevis $\triangle$ gadA & L. brevis CGMCC1306 derivative with gadA deleted & This work \\
\hline L. brevis $\triangle$ gadB & L. brevis CGMCC1306 derivative with gadB deleted & This work \\
\hline L. brevis $\triangle$ gadC & L. brevis CGMCC1306 derivative with gadC deleted & This work \\
\hline L. brevis $\triangle$ gadA $\triangle$ gadB & L. brevis CGMCC1306 derivative with both gadA and gadB deleted & This work \\
\hline L. brevis $\triangle$ gadB: pMG36e-gadB & L. brevis $\triangle$ gadB harboring pMG36e-gadB & This work \\
\hline L. brevis 9530 & L. brevis CGMCC1306 harboring the NICE system helper plasmid pNZ9530 & {$[28]$} \\
\hline L. brevis CK & L. brevis CGMCC1306 harboring pNZ9530 and pNZ8148 & {$[28]$} \\
\hline L. brevis 9530: pNZ8148-gadB & L. brevis 9530 harboring pNZ8148-gadB & This work \\
\hline L. brevis 9530: pNZ8148-gadCB & L. brevis 9530 harboring pNZ8148-gadCB & This work \\
\hline L. brevis 9530: pNZ8148-gadBC & L. brevis 9530 harboring pNZ8148-gadBC & This work \\
\hline \multicolumn{3}{|l|}{ Plasmids } \\
\hline pNZ8148 & $\mathrm{Cm}^{r}$, carries the nisin-inducible promoter $P_{\text {nisA }} ; 3.2 \mathrm{~kb}$ & Mobitec \\
\hline pMG36e & $E \mathrm{~m}^{r}$, constitutive expression vector with $P_{32}$ promoter; $3.6 \mathrm{~kb}$ & [43] \\
\hline pMG36e-gadB & $\mathrm{Em}^{r}$, gadB gene was cloned into pMG36e; $5.0 \mathrm{~kb}$ & This work \\
\hline pNZ8148-gadCB & $\mathrm{Cm}^{r}$, gadCB segment was cloned into pNZ8148; $6.1 \mathrm{~kb}$ & This work \\
\hline pNZ8148-gadB & $\mathrm{Cm}^{r}$, gadB segment was cloned into pNZ8148; $4.6 \mathrm{~kb}$ & This work \\
\hline pNZ8148-gadBC & $\mathrm{Cm}^{r}$, gadBC segment was cloned into pNZ8148; $6.1 \mathrm{~kb}$ & This work \\
\hline pGhost4 & $\mathrm{Em}^{r}$, integration vector, thermosensitive replicative plasmid in $L A B$, derivative of pGK12; $3.8 \mathrm{~kb}$ & {$[42]$} \\
\hline
\end{tabular}


(GYP) medium as described previously [29], with minor modifications $(\mathrm{g} / \mathrm{L})$ : glucose, 20; yeast extract, 15; peptone, 5; MSG, 75; $\mathrm{CH}_{3} \mathrm{COONa}, 3$; $\mathrm{FeSO}_{4} \cdot 7 \mathrm{H}_{2} \mathrm{O}, 0.001$; $\mathrm{MgSO}_{4} \cdot 7 \mathrm{H}_{2} \mathrm{O}, 0.03 ; \mathrm{NaCl}, 0.001 ; \mathrm{MnSO}_{4} \cdot 4 \mathrm{H}_{2} \mathrm{O}, 0.02$. In $48 \mathrm{~h}$ batch fermentations, temperature was maintained at $35{ }^{\circ} \mathrm{C}$, and the $\mathrm{pH}$ was kept constant at 5.2 or 6.8. To enhance GABA production, a two-stage $\mathrm{pH}$ and temperature control with substrate-feeding strategy was developed. The experiments were performed in a 5-L fermentor under the following conditions: medium volume $2 \mathrm{~L}$, inoculum size $10 \%(\mathrm{v} / \mathrm{v})$, agitation speed $100 \mathrm{rpm}$, and fermentation time $102 \mathrm{~h}$. In particular, after cultivation at pH 5.2 and $35{ }^{\circ} \mathrm{C}$ for $24 \mathrm{~h}$, the culture temperature and $\mathrm{pH}$ were changed and maintained at $40{ }^{\circ} \mathrm{C}$ and $\mathrm{pH} 4.4$, respectively, during the second phase (24-102 h). Additionally, 200-mL aliquots of MSG ( $140 \mathrm{~g}$ per aliquot) were supplemented into the bioreactor at $24 \mathrm{~h}, 36 \mathrm{~h}, 48 \mathrm{~h}$ and $72 \mathrm{~h}$, respectively. The $\mathrm{pH}$ was maintained at the set value with the addition of $3 \mathrm{~mol} / \mathrm{L} \mathrm{H}_{2} \mathrm{SO}_{4}$ or $3 \mathrm{~mol} / \mathrm{L}$ $\mathrm{NaOH}$.

\section{Amino acid comparison of GAD system genes and gene loci in LAB}

The $\operatorname{gadR}, \operatorname{gad} C, \operatorname{gadB}$, and $\operatorname{gad} A$ gene sequences of $L$. brevis ATCC367 (GenBank: CP000416) were used to identify homologous genes encoding $\operatorname{gadR}, \operatorname{gadC} \operatorname{gadB}$ and gadA in the genome of L. brevis CGMCC1306. Gene loci of putative GAD system genes in L. buchneri NRRL B-30929, L. sakei A156, L. brevis CGMCC1306, L. reuteri 100-23, L. plantarum WCFS1, L. acidophilus NCFM, L. lactis subsp. lactis CV56 and L. lactis subsp. cremoris MG1363 were analyzed with the BLASTx program against NCBI databases (http://blast.ncbi.nlm.nih.gov/ Blast.cgi). The sequences of GAD system proteins from various species were retrieved from NCBI and aligned to calculate similarity scores. Gene or protein sequences were aligned using ClustalX, and a phylogenetic tree was constructed with the neighbor-joining (NJ) method using MEGA 4.0. The gad genes in L. brevis CGMCC1306 were cloned and sequenced. The sequences of the $16 S \mathrm{rDNA}$, $\operatorname{gadR}, \operatorname{gadCB}$ operon and $\operatorname{gadA}$ were deposited in the GenBank database under accession numbers HQ726794, KU759571, JQ246952 and GU987102.1, respectively.

\section{Generation and verification of deletion mutants}

The chromosomal $\operatorname{gadA}$ gene was deleted in L. brevis CGMCC1306 as follows. DNA fragments of $735 \mathrm{bp}$ and 682 bp carrying the upstream and downstream regions of the gadA gene, respectively, were generated by PCR. These fragments contained KpnI/Pst and Pst $\mathrm{I} / X b a \mathrm{I}$ restriction sites at their $5^{\prime}$ and $3^{\prime}$ ends, respectively, which were introduced using $\operatorname{gadA}$ upstream and downstream primers (Additional file 5). The PCR-amplified products were digested with the corresponding restriction endonucleases, ligated, and cloned into the pGhost 4 vector $[37,42]$ and its derivative to generate pGh4- $\triangle$ gad $A-U$ and pGh4- $\operatorname{gad} A-U-D$, respectively. E. coli XL1-Blue cells were used as the intermediate host. The absence of PCR-induced mutations in the insert corresponding to the fused upstream and downstream regions of the gadA gene was verified by sequencing. The recombinant plasmid pGh4- $\triangle$ gadA-U-D was transformed into L. brevis by electroporation as described in our previous work [28]. The transformant was selected on MRS plates containing erythromycin at $28^{\circ} \mathrm{C}$. After homologous recombination into the chromosome, and clearing of the plasmid as previously described [37], the deletion was confirmed by colony PCR amplification using the flanking primers up F and down R. Similarly, L. brevis strains $\triangle \operatorname{gadB}$ and $\triangle \operatorname{gadC}$ were constructed, and the $\triangle \operatorname{gad} \triangle \triangle \operatorname{gadB}$ double mutant was further prepared using strain $\triangle g a d A$ as the template for homologous recombination of $\triangle g a d B$.

\section{Construction of plasmids and strains overexpressing key GAD system genes}

For overexpression of gad genes in L. brevis, $\operatorname{gadC}$, $\operatorname{gadB}$ and $\operatorname{gad} C B$ segments were amplified from the genomic DNA of strain L. brevis CGMCC1306. Information regarding the primers is listed in Additional file 6. The $\operatorname{gad} C B$ segment was amplified using the $\operatorname{gad} C B$-F and gadCB-R primer pair and ligated into the PstI and HindIII restriction sites of the vector pNZ8148 [39] to produce pNZ8148-gadCB. Similarly, the recombinant plasmids pNZ8148-gadB and pNZ8148-gadBC were obtained successively. E. coli MC1061 was used as the intermediate host and transformed with these constructs. The recombinant plasmids were confirmed by restriction enzyme analysis and DNA sequencing, and then transformed into L. brevis 9530 [28] (L. brevis CGMCC1306 harboring the facilitator plasmid pNZ9530) by electroporation. For expression of $\operatorname{gadB}$ in $L$. brevis $\triangle \operatorname{gadB}$, the $\operatorname{gadB}$ segment was amplified with primers $\operatorname{gadB}$-F2 and $\operatorname{gadB}$-R2, digested with SalI and HindIII, and then ligated into the constitutive expression vector pMG36e [43]. E. coli DH5 $\alpha$ was used as the intermediate host. The recombinant plasmid was also transformed into strain L. brevis $\triangle$ gadB to form L. brevis $\triangle$ gadB: pMG36e-gadB.

\section{Quantitative real-time PCR of gad genes}

The growth of $L$. brevis in GYP medium was monitored by measuring optical density (OD) at $600 \mathrm{~nm}$. Cells at different growth phases were harvested, and total RNA, stabilized with RNA protect Bacteria Reagent (Qiagen), was isolated in triplicate using RNeasy Mini Kit (Qiagen) according to the manufacturer's protocol. RNA quantification and quality assessment were carried out by 
UV spectrometry (OneDrop, OD-1000). For quantitative real-time PCR (qRT-PCR), extracted mRNAs were reverse transcribed to complementary DNA (cDNA) using the ReverTra Ace ${ }^{\circledR}$ qPCR RT kit (Toyobo Co., Ltd., Japan) and quantified via real-time PCR using SYBR $^{\circledR}$ Premix Ex TaqTM II (Takara). Relative expression of target genes was calculated according to the comparative $2^{-\Delta \Delta \mathrm{Ct}}$ method described by Livak and Schmittgen [44]. The 16S rRNA gene was used as a housekeeping gene, and a no-template control was used as a negative control. $\mathrm{Ct}$ values were normalized to the samples cultured for $6 \mathrm{~h}$ (control group). The primers used for housekeeping and gad genes are listed in Additional file 7. All quantitative PCRs were performed in triplicate with a StepOnePlus ${ }^{\text {TM }}$ Real-Time PCR System.

\section{Survival under acidic conditions}

To evaluate acid resistance, early stationary phase cells were obtained from cultures grown until the OD stopped increasing exponentially. The cells were then washed in $50 \mathrm{mmol} / \mathrm{L}$ potassium phosphate buffer $(\mathrm{pH} 7.0)$, and resuspended in $50 \mathrm{mmol} / \mathrm{L}$ potassium phosphate buffer $(\mathrm{pH} 2.5)$ to an $\mathrm{OD}_{600}$ of 1.0. A pH of 2.5 adjusted with $\mathrm{HCl}$ was chosen to match the conditions previously used to determine the effect of glutamate decarboxylase on acid resistance in $L$. reuteri [45]. Samples were collected after $0,1,3$, and $5 \mathrm{~h}$ of incubation at $\mathrm{pH} 2.5$ to monitor bacterial survival. For determination of bacterial survival, the samples were immediately mixed with phosphatebuffered saline (PBS, $137 \mathrm{mmol} / \mathrm{L} \mathrm{NaCl}, 2.7 \mathrm{mmol} / \mathrm{L} \mathrm{KCl}$, $10 \mathrm{mmol} / \mathrm{L} \mathrm{Na}_{2} \mathrm{HPO}_{4}$, and $2 \mathrm{mmol} / \mathrm{L} \mathrm{KH}_{2} \mathrm{PO}_{4}, \mathrm{pH}$ 7.4) and diluted in PBS prior to plating on MRS agar medium. The plates were incubated at $37^{\circ} \mathrm{C}$ for $48 \mathrm{~h}$, and colonies were counted to assess survival under lethal acidic conditions. Where indicated, $10 \mathrm{mmol} / \mathrm{L}$ of MSG was added.

\section{GAD activity assay}

Cell-bound GAD activity was determined by measuring the amount of GABA formed at $37{ }^{\circ} \mathrm{C}$ in a reaction mixture containing $0.1 \mathrm{mg}$ (dry cell weight) $/ \mathrm{mL}$ cell biomass, $0.2 \mathrm{~mol} / \mathrm{L}$ sodiumacetate buffer $(\mathrm{pH} 4.8)$, and $60 \mathrm{mmol} / \mathrm{L}$ MSG. One unit (U) of GAD activity was defined as the amount of cells that produced $1 \mu \mathrm{mol}$ of GABA in $1 \mathrm{~min}$ under the above conditions. Specific activity was defined as U/mg DCW cells. The cytoplasmic GAD activity of L. brevis was also determined. Cells were collected and lysed by passage three times through a French pressure cell press (Constant Cell Disruption Systems, UK) at 20,000 p.s.i., followed by centrifugation of the homogenate to remove cellular debris $\left(10,000 \times g, 4{ }^{\circ} \mathrm{C}, 10 \mathrm{~min}\right)$. The GAD activity of the supernatant fraction was determined. One unit $(\mathrm{U})$ of GAD activity was defined as the amount of enzyme that produced $1 \mu \mathrm{mol}$ of GABA in
$1 \mathrm{~min}$, and specific activity is expressed as U/mg of protein. Concentrations of Glu and GABA were determined by reversed-phase high-performance liquid chromatography (RP-HPLC), as described by Marquez et al. [46].

\section{Additional files}

Additional file 1. Figure S1. (A), Gene organization of the gad gene cluster in L. brevis CGMCC1306 (not drawn to scale). (B), Nucleotide sequence and expression signals of the gad gene cluster in L. brevis CGMCC1306. Parts of deduced amino acid sequences of the genes are given below the sequence. Facing arrows, inverted repeats; -10 and -35 promoter sequences are underlined and in boldface; vertical arrows, transcription stare points; rbs, ribosome-binding site (nucleotides indicated in lower case). Stop codons are indicated with asterisks; start codons are in bold face.

Additional file 2. Figure S2. (A), Transcription of gadR is independent from the gadCB operon. PCR results using gad $-\mathrm{F}_{1}$ and gad $-\mathrm{R}_{1}$ as primers. The expected band ( $573 \mathrm{bp})$ was only visible in the lane C. M: DNA marker; $\mathrm{A}: \mathrm{CDNA}$ as the template. $\mathrm{B}: \mathrm{mRNA}$ as the template. $\mathrm{C}$ : genome DNA as the template. gad- $\mathrm{F}_{1}$ : GTCAAACAACAATTGGCATC, gad- $\mathrm{R}_{1}$ : CAG CCGATAATGAAATACATC. (B), The gadB is co-transcribed in tandem with the upstream gadC gene. $P C R$ results using gad $-F_{2}$ and gad $-R_{2}$ as primers. The expected band ( $571 \mathrm{bp}$ ) was visible only in the lane A. M: DNA marker; $\mathrm{A}: \mathrm{CDNA}$ as the template $\mathrm{B}: \mathrm{mRNA}$ as the template. $\mathrm{gad}-\mathrm{F}_{2}:$ TATCTT GTACCGTTTCCACG, gad-R: ATACATCCTTCAGAAGAACC.

Additional file 3. Figure S3. Nisin-induced overexpression of GadB and GadC in L. brevis. (A): The nisin-controlled gene expression system consists of two compatible replicons: an essential helper plasmid, pNZ9530, encoding the nisRK regulatory genes, and the expression plasmid pNZ8148, bearing the nisA promoter $\left(P_{\text {nis }}\right)$. The gadB, gadBC or gadCB segments were under control of the nisin-inducible $P_{\text {nisA. }}$ (B): SDS-PAGE analysis of overexpression of GAD proteins. Cells were harvested after 6 hours of induction. Lane $\mathrm{M}$, protein size markers $(\mathrm{kDa})$. Lane 1 , L. brevis 9530: pNZ8148-gadCB; Lane 2, L. brevis 9530: pNZ8148-gadBC; Lane 3, L. brevis 9530: pNZ8148-gadB; Lane 4, L. brevis CK.

Additional file 4. Figure S4. Time courses of cell growth, GABA production and residual MSG during the two-stage fed-batch fermentation. The $L$. brevis $\mathrm{CK}$ was cultured in a 5-L fermentor under the following conditions: medium volume $2 \mathrm{~L}$, inoculum size $10 \%(\mathrm{v} / \mathrm{V})$, agitation speed $100 \mathrm{rpm}$, and fermentation time $102 \mathrm{~h}$. After cultivation at pH 5.2 and $35^{\circ} \mathrm{C}$ for $24 \mathrm{~h}$, the culture temperature and $\mathrm{pH}$ were changed and maintained at $40^{\circ} \mathrm{C}$ and 4.4, respectively, during the second phase (24-102 h). At 24 h, 36 h, $48 \mathrm{~h}$ and $72 \mathrm{~h}, 200-\mathrm{mL}$ aliquots of MSG (140 g per aliquot) were supplemented into the bioreactor. The $\mathrm{pH}$ was maintained at the set value with the addition of $3 \mathrm{~mol} / \mathrm{L} \mathrm{H}_{2} \mathrm{SO}_{4}$ and $3 \mathrm{~mol} / \mathrm{L} \mathrm{NaOH}$.

Additional file 5. Table S1. Primers used for PCR amplification.

Additional file 6. Table S2. Primers used for key GAD system genes amplification.

Additional file 7. Table S3. Primer used in the quantitative PCR.

\section{Abbreviations}

L. brevis: Lactobacillus brevis; GAD: glutamate decarboxylase; GABA: $\gamma$-aminobutyric acid; MSG: L-monosodium glutamate; GRAS: generally recognized as safe; DCW: $\mathrm{mg}$ dry cell weight; PCR: polymerase chain reaction; NCBI: National Center for Biotechnology Information; RP-HPLC: reversed phase high-performance liquid chromatography; SDS-PAGE: sodium dodecyl sulfate polyacrylamide gel electrophoresis.

\section{Authors' contributions}

$C J L, W R Z$ and $J H$ designed the experiments and prepared an initial draft manuscript. CJL, HF, YJH, CLP and SH conducted the experiments. LHM and 
SJY prepared and edited the manuscript. All authors read and approved the final manuscript.

\section{Author details}

${ }^{1}$ School of Biological and Chemical Engineering, Zhejiang University of Science and Technology, Hangzhou 310023, China. ${ }^{2}$ College of Chemical and Biological Engineering, Zhejiang University, Hangzhou 310027, China. ${ }^{3}$ School of Biotechnology and Chemical Engineering, Ningbo Institute of Technology, Zhejiang University, Ningbo 315100, China.

\section{Acknowledgements}

We would like to thank Professor Qing-sheng Qi (Shandong University) for providing strain E. coli MC1061 and his helpful technical assistance.

\section{Competing interests}

The authors declare that they have no competing interests.

\section{Availability of data and materials}

All data generated or analyzed during this study are included in this published article and in Additional files.

\section{Consent for publication}

Not applicable.

\section{Ethics approval and consent to participate}

Not applicable.

\section{Funding}

This work was supported by National Natural Science Foundation of China (Nos. 21176220, 31470793, 31670804) and Natural Science Foundation of Zhejiang Province (Nos. Z13B060008, LQ18B060002).

\section{Publisher's Note}

Springer Nature remains neutral with regard to jurisdictional claims in published maps and institutional affiliations.

Received: 17 August 2018 Accepted: 12 November 2018 Published online: 19 November 2018

\section{References}

1. Gaspar P, Carvalho AL, Vinga S, Santos H, Neves AR. From physiology to systems metabolic engineering for the production of biochemicals by lactic acid bacteria. Biotechnol Adv. 2013;31:764-88.

2. Heller KJ. Probiotic bacteria in fermented foods: product characteristics and starter organisms. Am J Clin Nutr. 2001;73:374s-9s.

3. Cotter PD, Hill C. Surviving the acid test: responses of gram-positive bacteria to low pH. Microbiol Mol Biol Rev. 2003;67:429-53.

4. Schiffrin EJ, Blum S. Food processing: probiotic microorganisms for beneficial foods. Curr Opin Biotechnol. 2001;12:499-502.

5. Quivey RG Jr, Kuhnert WL, Hahn K. Adaptation of oral streptococci to low pH. Adv Microb Physiol. 2000;42:239-74.

6. Krulwich TA, Sachs G, Padan E. Molecular aspects of bacterial pH sensing and homeostasis. Nat Rev Microbiol. 2011;9:330-43.

7. Lund P, Tramonti A, De Biase D. Coping with low pH: molecular strategies in neutralophilic bacteria. FEMS Microbiol Rev. 2014;38:1091-125.

8. van de Guchte M, Serror P, Chervaux C, Smokvina T, Ehrlich SD, Maguin E. Stress responses in lactic acid bacteria. Antonie Van Leeuwenhoek. 2002;82:187-216.

9. Sanders JW, Leenhouts K, Burghoorn J, Brands JR, Venema G, Kok J. A chloride-inducible acid resistance mechanism in Lactococcus lactis and its regulation. Mol Microbiol. 1998;27:299-310.

10. Feehily C, Karatzas KA. Role of glutamate metabolism in bacterial responses towards acid and other stresses. J Appl Microbiol. 2013:114:11-24

11. Lagerborg VA, Clapper WE. Amino acid decarboxylases of lactic acid bacteria. J Bacteriol. 1952:63:393-7.
12. Su MS, Schlicht S, Ganzle MG. Contribution of glutamate decarboxylase in Lactobacillus reuteri to acid resistance and persistence in sourdough fermentation. Microb Cell Fact. 2011;10(Suppl 1):S8.

13. Higuchi T, Hayashi H, Abe K. Exchange of glutamate and gamma-aminobutyrate in a Lactobacillus strain. J Bacteriol. 1997;179:3362-4.

14. Savage K, Firth J, Stough C, Sarris J. GABA-modulating phytomedicines for anxiety: a systematic review of preclinical and clinical evidence. P hytother Res. 2018;32:3-18.

15. Nemeroff $C B$. The role of GABA in the pathophysiology and treatment of anxiety disorders. Psychopharmacol Bull. 2003;37:133-46.

16. He S, Zhang Y, Wang D, Tao K, Zhang S, Wei L, Chen Q. Rapamycin/GABA combination treatment ameliorates diabetes in NOD mice. Mol Immunol. 2016;73:130-7

17. Li H, Cao Y. Lactic acid bacterial cell factories for gamma-aminobutyric acid. Amino Acids. 2010;39:1107-16.

18. Dhakal R, Bajpai VK, Baek KH. Production of GABA (gamma-aminobutyric acid) by microorganisms: a review. Braz J Microbiol. 2012;43:1230-41.

19. Wu Q, Shah NP. High gamma-aminobutyric acid production from lactic acid bacteria: emphasis on Lactobacillus brevis as a functional dairy starter. Crit Rev Food Sci Nutr. 2017:57:3661-72.

20. Qiu T, Huang GD, Cao YS. Production of gamma-aminobutyric acid by Lactobacillus brevis NCL912 using fed-batch fermentation. Microb Cell Fact. 2010;9:85

21. Lyu CJ, Zhao WR, Hu S, Huang J, Lu T, Jin ZH, Mei LH, Yao SJ. Physiology oriented engineering strategy to improve gamma-aminobutyrate production in Lactobacillus brevis. J Agric Food Chem. 2017;65:858-66.

22. Wu Q, Law YS, Shah NP. Dairy Streptococcus thermophilus improves cell viability of Lactobacillus brevis NPS-QW-145 and its gamma-aminobutyric acid biosynthesis ability in milk. Sci Rep. 2015;5:12885.

23. Wu Q, Tun HM, Law YS, Khafipour E, Shah NP. Common distribution of gad operon in Lactobacillus brevis and its GadA contributes to efficient GABA synthesis toward cytosolic near-neutral pH. Front Microbiol. 2017;8:206.

24. Wu Q, Shah NP. Restoration of GABA production machinery in Lactobacillus brevis by accessible carbohydrates, anaerobiosis and early acidification. Food Microbiol. 2018;69:151-8.

25. Yunes RA, Poluektova EU, Dyachkova MS, Klimina KM, Kovtun AS, Averina OV, Orlova VS, Danilenko VN. GABA production and structure of gadB/ gadC genes in Lactobacillus and Bifidobacterium strains from human microbiota. Anaerobe. 2016;42:197-204.

26. Schurr BC, Behr J, Vogel RF. Role of the GAD system in hop tolerance of Lactobacillus brevis. Eur Food Res Technol. 2013;237:199-207.

27. Li H, Li W, Liu X, Cao Y. gadA gene locus in Lactobacillus brevis NCL912 and its expression during fed-batch fermentation. FEMS Microbiol Lett. 2013;349:108-16.

28. Lyu C, Hu S, Huang J, Luo M, Lu T, Mei L, Yao S. Contribution of the activated catalase to oxidative stress resistance and gamma-aminobutyric acid production in Lactobacillus brevis. Int J Food Microbiol. 2016;238:302-10.

29. Huang J, Mei LH, Xia J. Application of artificial neural network coupling particle swarm optimization algorithm to biocatalytic production of GABA. Biotechnol Bioeng. 2007:96:924-31.

30. de Ruyter PG, Kuipers OP, Beerthuyzen MM, van Alen-Boerrigter I, de Vos WM. Functional analysis of promoters in the nisin gene cluster of Lactococcus lactis. J Bacteriol. 1996;178:3434-9.

31. Azcarate-Peril MA, Altermann E, Hoover-Fitzula RL, Cano RJ, Klaenhammer TR. Identification and inactivation of genetic loci involved with Lactobacillus acidophilus acid tolerance. Appl Environ Microbiol. 2004;70:5315-22.

32. Teixeira JS, Seeras A, Sanchez-Maldonado AF, Zhang C, Su MS, Ganzle MG. Glutamine, glutamate, and arginine-based acid resistance in Lactobacillus reuteri. Food Microbiol. 2014:42:172-80.

33. De Biase D, Pennacchietti E. Glutamate decarboxylase-dependent acid resistance in orally acquired bacteria: function, distribution and biomedical implications of the gadBC operon. Mol Microbiol. 2012;86:770-86.

34. Waterman SR, Small PL. Identification of $\sigma^{5}$-dependent genes associated with the stationary-phase acid-resistance phenotype of Shigella flexneri. Mol Microbiol. 1996:21:925-40.

35. Grassini G, Pennacchietti E, Cappadocio F, Occhialini A, De Biase D. Biochemical and spectroscopic properties of Brucella microti glutamate decarboxylase, a key component of the glutamate-dependent acid resistance system. FEBS Open Bio. 2015:5:209-18. 
36. Sa HD, Park JY, Jeong SJ, Lee KW, Kim JH. Characterization of glutamate decarboxylase (GAD) from Lactobacillus sakei A156 isolated from jeot-gal. J Microbiol Biotechnol. 2015;25:696-703.

37. Maguin E, Prevost H, Ehrlich SD, Gruss A. Efficient insertional mutagenesis in lactococci and other gram-positive bacteria. J Bacteriol. 1996;178:931-5.

38. Ma D, Lu P, Yan C, Fan C, Yin P, Wang J, Shi Y. Structure and mechanism of a glutamate-GABA antiporter. Nature. 2012;483:632-6.

39. Mierau I, Kleerebezem M. 10 years of the nisin-controlled gene expression system (NICE) in Lactococcus lactis. Appl Microbiol Biotechnol. 2005;68:705-17.

40. Cotter PD, Gahan CG, Hill C. A glutamate decarboxylase system protects Listeria monocytogenes in gastric fluid. Mol Microbiol. 2001;40:465-75.

41. Hersh BM, Farooq FT, Barstad DN, Blankenhorn DL, Slonczewski JL. A glutamate-dependent acid resistance gene in Escherichia coli. J Bacteriol. 1996:178:3978-81.
42. Maguin E, Duwat P, Hege T, Ehrlich D, Gruss A. New thermosensitive plasmid for gram-positive bacteria. J Bacteriol. 1992;174:5633-8.

43. van de Guchte M, van der Vossen JM, Kok J, Venema G. Construction of a lactococcal expression vector: expression of hen egg white lysozyme in Lactococcus lactis subsp. lactis. Appl Environ Microbiol. 1989;55:224-8.

44. Livak KJ, Schmittgen TD. Analysis of relative gene expression data using real-time quantitative $P C R$ and the $2^{-\triangle \Delta C T}$ method. Methods. 2001;25:402-8.

45. Su MS, Schlicht S, Ganzle MG. Contribution of glutamate decarboxylase in Lactobacillus reuteri to acid resistance and persistence in sourdough fermentation. Microb Cell Fact. 2011;10:S8.

46. Marquez FJ, Quesada AR, Sanchezjimenez F, Decastro IN. Determination of 27 Dansyl amino acid derivatives in biological fluids by reversed phase high performance liquid chromatography. J Chromatogr. 1986;380:275-83.
Ready to submit your research? Choose BMC and benefit from:

- fast, convenient online submission

- thorough peer review by experienced researchers in your field

- rapid publication on acceptance

- support for research data, including large and complex data types

- gold Open Access which fosters wider collaboration and increased citations

- maximum visibility for your research: over $100 \mathrm{M}$ website views per year

At BMC, research is always in progress.

Learn more biomedcentral.com/submissions 